\title{
PRACTITIONER OF EFL FOR NON-ENGLISH MAJOR UNDERGRADUATES: SPECIFIC PROFESSIONAL NEEDS
}

\author{
Oksana Bigych $^{1}$, Oksana Matsnieva ${ }^{2}$ \\ Kyiv National Linguistic University, Kyiv, Ukraine \\ E-Mail: ${ }^{1}$ bkbpearl@gmail.com, ${ }^{2}$ oksanamatsnieva@gmail.com
}

\begin{abstract}
The paper deals with the problem of forming the methodological competence of a prospective practitioner of EFL for non-English major undergraduates. Foreign language learning environments training English and non-English majors have been comparatively analysed from the point of view of the teaching objective, result, content, process and resources. On the basis of the analysis, specific professional needs of a practitioner of EFL for non-English majors have been singled out. They encompass such components of the practitioner's professional activity as research, designing, organizing, self-education, and collaboration. Research and designing include students' educational and job-related needs investigation, academic and professional discourse analysis, teaching objective specification, teaching content selection, course syllabus development, teaching materials selection, adaptation and development. Organizing focuses on the application of the functional approach to EFL acquisition, computer-assisted learning, distance learning, blended learning, content and language integrated learning (CLIL), role plays, business games, simulations, differentiation strategies in the groups with the heterogeneous input level of the students' intercultural communicative competence and low level of motivation to foreign language learning. Self-education presupposes developing a positive attitude to the students' field, monitoring the latest news and achievements in it, mastering the basics of the students' major, its terminology, genre and discourse peculiarities. Collaboration includes cooperation with students, readiness to be corrected by them when a solecism in the subject is made by the practitioner and collaboration with a teacher of the students' major while selecting the teaching content, designing the course and in team teaching. The singled out peculiarities are to be taken into consideration while designing the structure of the methodological competence of a practitioner of EFL for nonEnglish major undergraduates.
\end{abstract}

Key words: ESP practitioner, practitioner of EFL for non-English major undergraduates, methodological competence, professional needs

\section{INTRODUCTION}

Nowadays Ukrainian specialists of different fields are expected to have a good command of English. It goes without saying that among various factors which affect the process of achieving the goal much depends on the methodological competence of an 
ESP practitioner, or a practitioner of EFL for non-English major undergraduates to be exact. As recent studies (Bolitho and West 2017) claim, the latter leaves much to be desired. Having analysed researches on the problem, we came to the following conclusion. While the competences of an EFL school teacher and a practitioner of EFL for English major undergraduates are deeply investigated, there are very few researches which solve the problem of forming the competence of a practitioner of EFL for nonEnglish major undergraduates. As a result, most teacher education university programmes in Ukraine include basic courses of the methodology of teaching EFL at school and to students majoring in English. On the other hand, practitioners of EFL to non-English major undergraduates confirm the fact that they face a lot of difficulties caused by lack of special training. Teacher educators (Bobyr 2018) point out a number of methodological errors novice teachers make transferring their knowledge and experience of learning English as their major into teaching non-English major undergraduates.

At some institutions of higher education, the problem is solved with in-service teacher training (Krupchenko, Inozemtzeva and Prilipko 2015). Considering it a good way out, we also support the idea of pre-service teacher training at tertiary level which is to be based on the formed competences of an EFL school teacher and a practitioner of EFL for English major undergraduates. Such methodology requires a detailed structure of the competence of a practitioner of EFL for non-English major undergraduates that can be worked out on the basis of his/her specific needs analysis.

The aim of this article is to single out the specific professional needs of a practitioner of EFL for non-English major undergraduates.

\section{METHOD}

To achieve the stated aim, the foreign language learning environments training English and non-English major undergraduates are to be comparatively analysed from the point of view of the objective, content, process, result and resources.

\section{FOREIGN LANGUAGE LEARNING ENVIRONMENT}

\subsection{Definition}

In our research learning environment is considered to be a multi-level system of conditions, circumstances, factors and possibilities which provide the subject of education with the optimal parameters of the educational activity.

\subsection{Objective and Result}

Basing on the tree of English Language Teaching suggested by Hutchinson and Waters (1987), we came to the conclusion that both foreign language learning environments deal with ESP. Such teaching aims at forming a professionally marked secondary language personality and is based on the learner-centered, competence- and level-based, action- and professionally-oriented approaches. Being of great importance, the latter determines the teaching objective as professional intercultural communicative 
competence which is a component of a graduate's professional competence and is defined as his/her integrative ability to solve job-related tasks with the help of a foreign language.

Despite similar objective and result, the two learning environments are characterized by distinctive features. The one training students majoring in English aims at forming a professionally marked secondary language personality of a future EFL teacher or of a translator/interpreter. According to the current curriculum, the target level of the professional intercultural communicative competence for the graduates is C2 (Mastery).

As for the learning environment training non-English major undergraduates, its result is a professionally marked secondary language personality of a specialist of some nonlinguistic field. The target level of the professional intercultural communicative competence varies depending on the graduates' field. According to the current curriculum (Bakayeva et al. 2005), specialists of some fields, e.g. prospective lawyers and doctors, are to achieve $\mathrm{C} 1$ (Effective) level of the professional intercultural communicative competence while the target level for future engineers is B2 (Vantage). Hence, foreign language education requires diversification and within the framework of the learning environment training non-English majors the teaching objective is determined as diversified professional intercultural communicative competences.

Due to a great variety of professional contexts which are dynamically developing nowadays, precise correlation between the fields and the levels has not been introduced yet. Practitioners of EFL for non-English majors are expected to adapt the general objective to the needs of a certain field.

\subsection{Content}

Practitioners' professional activity within the framework of both learning environments presupposes selecting the teaching content which includes job-related spheres and types of communication, functions, psychological and communicative situations and roles, non-verbal means of communication; communicative objectives and intentions; topics, subject matters and texts; language and lingua-socio-cultural material; learning and communicative strategies; knowledge, language habits and speech skills.

A practitioner of EFL for English major undergraduates deals with three professional contexts only - of an EFL teacher, an interpreter or a translator. For him/her the process of content selecting is facilitated with the fact that he/she is a graduate of the same or similar department and is a specialist of the graduates' field or at least had/has a certain experience of working in it (work as an EFL school teacher and a translator or interpreter is meant). Consequently, within the framework of this learning environment the graduates' and the practitioner's academic and professional contexts partially or fully coincide. Thus, the practitioner is well aware of the students' communicative needs. $\mathrm{He} / \mathrm{she}$ does not face any difficulties while identifying job-related spheres and types of communication, modelling academic and professional situations, selecting professionally-oriented language and lingua-socio-cultural material.

As it was mentioned above, practitioners of EFL for non-English majors are expected to specify the components of the graduates' professional intercultural communicative competence due to the need for the diversification of the foreign language education. It requires investigation of the peculiarities of the graduates' professional activity. According to Basturkmen (2014), such investigation presupposes several kinds of analysis, i.e. target situation analysis (identification of tasks, activities and skills learners 
are/will be using English for), discourse analysis (descriptions of the language used in the target situation), present situation analysis (identification of what students do and do not know, can and cannot do in relation to the demands of the target situation), learner factor analysis (their motivation, how they learn and their perception of their needs), teaching context analysis (analysis of the factors related to the environment in which the course will run, consideration of what realistically the ESP course and teacher can offer). Taking this into account, we can conclude that research and designing skills make the basis of the professional activity of a practitioner of EFL for non-English major undergraduates. Such skills include

- students' academic and professional needs analysis;

- specification of the job-related spheres and types of communication, functions, psychological and speech situations and roles, non-verbal means of communication related to the academic and professional needs and contexts;

- identification of the typical communicative objectives and intentions in the jobrelated situations;

- differentiation between EFL teaching aims;

- topics and subject matters selection;

- academic and professional discourse analysis;

- active and passive language minimum identification;

- job-related language and lingua-socio-cultural material selection;

- research methods (observation, questionnaire, interview, conversation, test etc.) usage;

- ESP course syllabus development.

For a practitioner of EFL for non-English major undergraduates accomplishing the enlisted tasks is complicated with the fact that as a rule he/she is not a specialist of the students' field. Furthermore, the number of professional contexts a contemporary practitioner deals with may vary from one to several. At the same time, Bojovic (2006) claims that a professional ESP teacher must be able to switch from one professional field to another without being obliged to spend months on getting started. Thus, the practitioners' skills of self-education and collaboration with the students and their major subject specialists are of vital importance. The former is aimed at

- developing a positive attitude to the student's field,

- monitoring the latest news and achievements in it,

- mastering the basics of the students' major, its terminology, genre and discourse peculiarities.

The latter presupposes cooperation and collaboration with the major subject teachers aiming at

- teaching objective and content specification,

- job-related language and lingua-socio-cultural material selection,

- course designing,

- integrative means of the professional intercultural communicative and subject matter competences test and assessment development. 


\subsection{Resources}

Resources encompass the number of ECTS credits allotted by the institution of higher education on EFL as a university subject and the availability of the course-books which correlate with the teaching objective and content. Within the framework of the foreign language environment training English majors, EFL is one of the core subjects of the undergraduates' professional education programme. Students doing Bachelor's degree study it for four years, those doing Master's degree study it for a year and a half. The average number of ECTS credits allotted on it by the institutions of higher education in Ukraine is 107 (3210 academic hours, 1358 of which are practical classes).

As for the foreign language environment training non-English majors, EFL is one of the compulsory subjects of the undergraduates' general education programme. At most Ukrainian institutions of higher education students doing Bachelor's degree study it during the first two years only. The average number of ECTS credits allotted is 9 (270 academic hours, 90 of which are practical classes). Graduates that require $\mathrm{C} 1$ level of the professional intercultural communicative competence (e.g. prospective lawyers, ITspecialists) continue to study it while doing Master's degree. The average number of ECTS credits is 6 (180 academic hours, 60 of which are practical classes). At the same time, the authors of the current curriculum (Bakayeva et al. 2005) state that achieving B2 level of the intercultural communicative competence on the basis of B1+ (in Ukraine it is the level of the intercultural communicative competence achieved by a graduate of a senior school specializing in EFL learning, the input level of the intercultural communicative competence of the majority of non-English major undergraduates is much lower) requires at least 396 academic hours, 270 of which are to be practical classes. Taking this into account, we can conclude that because of a very limited number of ECTS credits allotted a practitioner of EFL for non-English major undergraduates is expected to intensify the learning process.

Having compared availability of course-books for both learning environments, we came to the conclusion that the environment training non-English major undergraduates is characterized by a lower level of it which is caused by the aforementioned variety of contemporary professional contexts and the need for the diversification of the professional foreign language education. Experienced practitioners point out that the majority of available course-books do not correlate with the teaching objective and content either partially or totally. As a result, a practitioner of EFL for non-English majors is to be able to select and adapt course-books, to develop his/her own ones (either alone or cooperating with the subject specialist) relevant for the students' specific needs and the number of ECTS credits available.

\subsection{Process}

As both learning environments under analysis deal with ESP, the foreign language teaching and learning processes within them have a lot in common. Still, the singled out peculiarities of the teaching objective, result, content and resources determine the distinctive features of each of them. While the system approach is considered to be appropriate for language acquisition by English major undergraduates, the functional approach should dominate in teaching English to non-English majors (Bobyr 2018). The 
former helps penetrate deep into the language system which is good and possible, due to the number of ECTS credits available, for the students majoring in English. The latter focuses non-English major students' attention on mastering the means of communication they will need to express themselves and to understand others successfully.

Among different teaching methods and techniques essential for training non-English major undergraduates computer-assisted learning, distance learning, blended learning, content and language integrated learning (CLIL) (including integrating language and content in higher education (ILCLHE), content-based instruction (CBI), English as a medium of instruction (EMI), foreign language learning through total, partial and sheltered immersion), role-plays, business games and simulations are to be emphasized. However, application of some of them turns to be a challenge for a practitioner of EFL for non-English major undergraduates due to the aforementioned fact that he/she is not a specialist of the students' field. Lack of the subject knowledge requires cooperation with the students, readiness to be corrected by them when a solecism is made, and collaboration with the students' major subject teacher within team teaching.

Coincidence, in the majority of cases, of the students' and the practitioner's types of cognitive thinking (the argument for it is the fact that they both chose the same or similar professional context), appropriate input level of the students' intercultural communicative competence and their relatively high level of motivation to mastering the foreign language facilitate the education process within the framework of the learning environment training English major undergraduates.

For a practitioner of EFL to non-English majors, on the other hand, this process is complicated with the difference, in the majority of cases, between the students' and the practitioner's types of cognitive thinking (it results into belonging to different, sometimes diametrically opposite, professional contexts), heterogeneous and often inadequate input level of the students' intercultural communicative competence, their low level of motivation to mastering the foreign language. Thus, a practitioner of EFL for non-English majors is expected:

- to be aware of the type of cognitive thinking which is characteristic of the specialists of a certain field,

- to be able to function as a facilitator who presents the language phenomenon in the way appropriate for the students' type of cognitive thinking (Cherkashina 2017),

- to apply differentiation strategies in groups with the heterogeneous level of the students' intercultural communicative competence,

- to foster undergraduates' motivation to foreign language acquisition.

The last but not the least distinctive feature of the learning environments under analysis is connected with the phenomenon of "subjective theories" according to which classes of EFL at the University turn to be a pattern and a model of the EFL teacher's future professional activity. While imitating effective patterns by a practitioner of EFL for English major undergraduates may lead to some positive teaching result, such imitation within the framework of the learning environment training non-English majors is usually marked either by its absence or by some negative result. 


\section{CONCLUSION}

Comparative analysis of the foreign language learning environments training English and non-English major undergraduates from the point of view of the teaching objective, result, content, process and resources allowed us to single out the specific professional needs of the practitioner of EFL for non-English majors. Such needs comprise research, designing, organizing, self-education and collaboration.

Making the basis of the practitioner's professional activity, research and designing presuppose students' academic and professional needs analysis: job-related spheres and types of communication, functions, psychological and speech situations and roles, nonverbal means of communication specification; typical communicative objectives and intentions in the job-related situations identification; EFL teaching aims specification; topics, subject matters, job-related language and lingua-socio-cultural material selection; academic and professional discourse analysis; active and passive language minimum specification; research methods application; ESP course syllabus development; teaching materials selection, adaptation and development.

Organizing deals with the implementation of the functional approach to EFL acquisition, application of such teaching methods and techniques as computer-assisted learning, distance learning, blended learning, content and language integrated learning, role plays, business games, simulations, etc., usage of differentiation strategies in the groups with the heterogeneous input level of the intercultural communicative competence, functioning as a facilitator who presents the language phenomenon in the way appropriate for the students' cognitive type of thinking, and fostering students' motivation to foreign language learning.

The fact that in the majority of cases the practitioner of EFL for non-English majors is not a specialist of the students' field determines the specific content of self-education and collaboration within his/her professional activity. The former aims at developing a positive attitude to the students' field, monitoring the latest news and achievements in it, acquiring the basics of the students' major, its terminology, genre and discourse peculiarities. The latter includes cooperation with students, readiness to be corrected by them when a solecism in the field is made, and collaboration with the students' major subject teacher while teaching objectives specification, teaching content and materials selection and team teaching implementation. The singled out specific professional are to be taken into consideration while designing the structure of the methodological competence of such a practitioner.

\section{REFERENCES}

Bakayeva, Galyna, Oksana Borysenko, Victoria Ivanischeva, Alla Khodtseva, Liudmila Klymenko, Svitlana Kostrytska, Tetyana Kozymyrska, Tetyana Skrypnyk, Nataliya Todorov, and Iryna Zuyenok. English for Specific Purposes National Curriculum for Universities. Kyiv: Lenvit, 2005.

Basturkmen, Helen. "LSP teacher education: Review of literature and suggestions for the research agenda." Ibérica, no. 28, 2014. <http://www.redalyc.org/html/2870/287032049002/> (21 August 2018).

Bobyr, Svitlana. "The Errors the novice ESP teachers make in their classes." In ELT in Ukraine: New Ways to Success, edited by Alla Radu. Lviv: Marusych, 2018, 20-21. 
Bolitho, Rod, and Richard West. The Internationalisation of Ukrainian universities: the English language dimension. Kyiv: Stal, 2017.

Bojović, Milevica. "Teaching Foreign Language for Specific Purposes: Teacher Development." 2006. <DOI: 10.13140/2.1.4011.4566> (21 August 2018).

Cherkashina, Elena. "The Model of Teaching a Foreign Language for Specific Purposes in a Technical University." Russian Linguistic Bulletin, no. 2(10) (2017): 46-50.

Hutchinson, Tom and Alan Waters. English for Specific Purposes: A learning-centered approach. Cambridge: Cambridge University Press, 1987.

Krupchenko, Anna, Inozemtzeva, Kira, and Prilipko, Elena. "Professional Development of a Foreign-Language Tertiary Teacher: Competence-Based Approach." Mediterranean Journal of Social Sciences, v. 6, n. 6, S5, December, 2015. <http://www.mcser.org/journal/index.php/mjss/article/view/8555> (21 August 2018). 